DOI: https://doi.org/10.32782/2410-0927-2020-12-9

УДК 81(71=161.2) “19”(092):811.161.2’272](045)

Г 20

Леся Гапон

\title{
ЛІНГВІСТИЧНІ СТУДІЇ ЯРОСЛАВА-БОГДАНА РУДНИЦЬКОГО В КАНАДІ ЯК ФЕНОМЕН ДОБИ ІДЕОЛОГІЧНОГО ПРОТИСТОЯННЯ
}

У статті проаналізовано праці Я. Рудницького канадського періоду (1949-1995 рр.) - доби ідеологічного протистояння радянської та західної систем - 3 метою виявлення впливу наукової позиції вченого діаспори на розвиток окремих галузей сучасної української лінгвістики.

Стисло схарактеризовано наукову діяльність Я. Рудницького в Канаді, висвітлено погляди мовознавця на роль славістів діаспори в період тоталітарного тиску на україністику в СРСР.

Продемонстровано вагому роль ученого в боротьбі за збереження правописних норм харківського правопису як у середовищі емігрантів, так і в материковій Україні. Наведено факти особистої участі Я. Рудницького в наукових дискусіях та громадсько-політичних акціях стосовно необхідності повернення в українську абетку літери “г”, відновлення окремих відмінкових форм та транслітерації іншомовних запозичень.

Доведено стійку позицію Я. Рудницького щодо підтримки української наукової термінолексики, утвореної на базі питомих слів за українськими дериваційними моделями.

Значну увагу приділено соціолінгвістичному напряму канадських мовознавчих студій автора стосовно умов розвитку української мови в УРСР. Окреслено ключові аспекти концепції “лінгвіциду”(мововбивства), автором якої $\epsilon$ Я. Рудницький, висвітлено основні “лінгвіцидні” фактори, наголошено на важливості використання вченим можливостей демократичної системи Заходу в процесі виборювання права української мови на самостійний розвиток і державний захист.

У дослідженні використано біографічний метод, метод аналізу лінгвістичної літератури, зіставний та актуалізаційний методи.

Погляди автора подані в порівнянні із висновками сучасних українських дослідників. Опис лінгвістичних процесів стосовно особливостей становлення і розвитку української соціолінгвістики, наукової термінології та правописних норм відтворено з урахуванням впливу на них історичних та соціокультурних чинників доби ідеологічного протистояння радянської та західної систем із проєкцією на сьогодення.

Ключові слова: лінгвоісторіографія, діаспора, правопис, наукова термінологія, соціолінгвістика, лінгвоцид.

Вступ. Лінгвоісторіографія як мовознавча галузь покликана вивчати наукову творчість забутих або малознаних постатей, переосмислити усталені факти й матеріали, щоб неупереджено репрезентувати історію українського мовознавства, є особливо актуальною в наш час - час подолання стереотипів іпошуку нових історико-філософських сенсів. Історично склалося так, що українське мовознавство в СРСР (1922-1991 рр.) розвивалося нерівномірно. 3 одного боку, як зазначає П. Селігей, “видано сотні фундаментальних монографій, граматик, підручників, збірників, укладено десятки словників, написано безліч статей і дисертацій”, щоб кожен охочий міг оволодіти нормами української літературної мови, з іншого боку - були напрями, які не мали “вільного розвитку, потерпаючи від ідеологічних регламентацій влади", а сфера вживання української літературної мови звузилася до критичного рівня [9, с. 7 ]. До 1992 року за залізною завісою залишалися мовознавчі здобутки визначних учених діаспори: О. Горбача, І. Зілинського, О. Колесси, 3. Кузелі, І І. Огієнка, М. Пшеп’юрської-Овчаренко, С. Рабій-Карпінської, В. Розова, Р. Смаль-Стоцького, В. Чапленка, Ю. Шевельова та інших. На думку відомого українського мовознавця П.Гриценка, вони “у неслов'янському оточенні розбудовували україністику й славістику”, їхній внесок “був значним, а для розвитку деяких напрямів - визначальним" [2, с. 118].

Одним із подвижників української науки в еміграції був Я. Рудницький (1910-1995рр.) мовознавець, фольклорист, публіцист, бібліограф, літературознавець, педагог, авторитетний громадсько-політичний діяч іорганізатор науки, чиї праці 3 ономастики, етимології, діалектології, соціальної лінгвістики та перший друкований "Етимологічний словник української мови” (1962-1982) увійшли в історію світової україністики.

Про наукові здобутки Я. Рудницького писали дослідники діаспори: А. Власенко-Бойцун, О. Войценко, М. Мандрика, Т. Носко-Оборонів, Т. Примак, Я. Пришляк, Я. Славутич.

(C) Гапон Л., 2020 
Спеціальних лінгвоісторіографічних робіт вітчизняних учених порівняно небагато. У статтях Я. Дзири, Л. Дегтяренко й О. Супронюк, Г. Дідківської, Р. Зорівчак, В. Шендеровського окреслено основні напрями мовознавчих досліджень Я. Рудницького, а в розвідках 3. Бичка i С. Гірняк фрагментарно репрезентовано його внесок у вивчення територіальних і соціальних діалектів української мови. Комплексне дослідження лінгвістичного доробку відомого славіста репрезентовано в монографії “Мовознавча спадщина Ярослава-Богдана Рудницького” Л. Гапон. Однак 3 огляду на вагомість постаті Я. Рудницького в українській лінгвоісторіографії, величезний діапазон наукових інтересів ученого та можливість використання цінних здобутків його мовознавчої діяльності для розвитку вітчизняної науки, висвітлення окремих аспектів його наукової діяльності вважаємо актуальним.

Мета статті - проаналізувати лінгвістичні студії Я. Рудницького доби ідеологічного протистояння із проєкцією на сучасний стан розвитку вітчизняного мовознавства.

Основним завданням вважаємо висвітлення ролі українсько-канадського вченого в процесі збереження правописних норм української літературної мови та наукової термінології, державного захисту мовних прав українців, утвердження самодостатності української мовознавчої науки на міжнародній арені у 1949-1995 рр. ХХ століття.

Методи та методики дослідження. В основі методології дослідження використано метод аналізу лінгвістичної літератури і генералізації провідних ідей, прийоми культурноісторичного та біографічного методів. Метод зіставлення дозволив порівняти трактування відомим славістом діаспори певних мовних явищ із поглядами радянських та сучасних українських мовознавців. Використано також актуалістичний метод дослідження, який "полягає у використанні сучасних знань для вивчення минулого та передбачення майбутнього” [1, с. 6]. Теоретико-методологічна основа роботи грунтується на основних положеннях праць як Я. Рудницького, так і інших українських та зарубіжних мовознавців.

Результати та дискусії. Канадський період життя Я. Рудницького (1949-1995рp.), що припадає на розпал холодної війни (1946-1986 рр.), багатий на знакові для української науки в Канаді події. 1949 року в Манітобському університеті міста Вінніпегу вчений започаткував роботу Департаменту славістики й україністики, який очолював упродовж 1949-1977 pp., разом із Д. Дорошенком та І. Білецьким відновив діяльність Української вільної Академії наук у Канаді, упродовж 1954-1974 pp. був іiі очільником. Великою заслугою вченого-патріота стало відновлення у 1978 році Могилянсько-Мазепинської Академії наук, у якій він головував упродовж 1978-1992 pp. Важливу роль для популяризації україніки в Канаді відіграла багаторічна робота Я. Рудницького в осередку української культури і освіти у Вінніпезі, а також у Товаристві плекання рідної мови. Упродовж 1964-1989 рр. учений редагував часопис "Слово на сторожі”, а впродовж 1971-1979 pp. та 1982-1988 pр. очолював Товариство плекання української мови [3, с. 525].

У праці Я. Рудницького “Українська славістика та іiі завдання" (1948) йдеться про існування “двох українських славістик: соціялістичної і емігрантської”. Автор переконував, що в країні з тоталітарним режимом будь-які наукові студії покликані викривлювати дійсність на користь панівної ідеології і “з огляду на це увесь тягар наукової української славістики спадає на плечі українських учених-емігрантів в Европі і в Америці” [8, с. 21]. Свідченням цього $\epsilon$ філологічні праці Я. Рудницького канадського періоду (1949-1995рр.), які стали провісниками позитивних тенденцій у розвитку сучасної мовознавчої науки.

Особливої гостроти в роботах Я. Рудницького набувають проблеми збереження правописних норм української літературної мови та наукової термінології. У 30 -тих рр. XX ст. в УРСР розпочався стрімкий процес деукраїнізації. Заборонено ухвалений 1928 року харківський правопис (головний редактор - О. Синявський), який, на думку багатьох лінгвістів, найточніше відбивав внутрішні закони української мови. 1930 року Інститут української наукової мови було ліквідовано, укладені раніше термінологічні словники вилучено з ужитку. 1933 року народний комісар освіти УРСР М. Скрипник схвалив інший правопис, який штучно “зближував", уніфіковував українську й російську мови. 3 алфавіту вилучено літеру $\boldsymbol{t}$, а всю українську наукову термінологію узгоджено з російсько-українськими словниками. Український 
правопис за редакцією М.Грунського (1940) і визнаний офіційним в УРСР Український правопис за редакцією Л.Булаховського (1946), на думку В. Сімовича і Я. Рудницького, засвідчують “дальше проведення російського курсу” [10]. Український правопис 1960 року, що був укладений під впливом виданих у 1959 році “Правил русской орфографии и пунктуации”, залишався чинним до 1989 року.

Натомість у Західній Україні до 1939 року та в діаспорі було збережено правописні правила, ухвалені 1928 року. I хоча в 1941-1942 pр. вийшли друком два видання Українського правопису І. Зілинського (без уживання в українській мові апострофа і “з деякими дрібними відхиленнями в написанні чужих слів"), уже 1943 року “вся еміграція” повернулася до харківського правопису [10].

Виключно на його норми спирався Я. Рудницький, наголошуючи, що в укладанні правопису 1928 року “брали участь безпосередньо або посередньо представники всіх українських земель та еміграціі”, тому “треба дивитися на нього як на вислів соборництва на правописному полі й треба вважати його за єдинообов'язковий” [10]. До будь-яких спроб змінити харківські правописні норми - як з боку радянських учених, так і з боку представників діаспори - мовознавець ставився несхвально.

Норми харківського правопису утверджено в низці тематичних публікацій Я. Рудницького канадського періоду: "Український правопис" (1949), “Як писати політературному”(1951), “Чи дискусія на тему українського правопису потрібна?” (1952), “Правописний словник української мови” (співавтор - К. Церкевич, 1979), “Сучасна українська граматика" Я. Рудницького (співавтор - Ю. Луцький, 1949, 1968, 1979), а також в "Етимологічному словнику української мови" (1962-1982 рр.), перший випуск якого на 20 років випередив етимологічне словникарство материкової України. Словник написано англійською мовою, україномовний матеріал оформлено згідно 3 правилами харківського правопису. Українські слова, написання яких відбиває норми русифікованих радянських правописів, Я. Рудницький подекуди вводить у словникові гасла 3 позначкою SovUk. (з англ.: радянські українські): вольонте́ - SovUk.: волонте́p [12, т. I, с. 474]; таля́ нтний - SovUk.: гала́ нтний [12, т. I, с. 794]; тніт - SovUk.: zніт [12, т. I, с. 849]; erída - SovUk.: ezída [13, т. II, с. 243]; ке́мпінг-SovUk.: ке́мпінг [13, т. II, с. 654]; керосина-SovUk.: кероси́н [13, т. II, с. 656]; кля́ са-SovUk.: клас [13, т. II, с. 684].

Надзвичайно обурило вченого вилучення з алфавіту літери “г”. 1975 року на VIII Міжнародному конгресі фонетистів у Лідському університеті (Англія), Я. Рудницький виголосив доповідь “Про заборону української букви “г” в Радянському Союзі" [16, с. 342]. Цього ж року вчений надіслав Канадській національній комісії Об’єднаних Націй, освітній, науковій i культурній організації ЮНЕСКО меморандум про необхідність повернення літери “г” до української азбуки. Я. Рудницький переконливо доводив, що ця літера існувала в українському алфавіті з XVII ст., а 1933 року іï “насильницьки” вилучили з обігу. I хоча в 60-70-тих роках XX ст. в СРСР визнали право на існування фонеми [r] в українській мові, але не дали жодних рекомендацій щодо іï позначення на письмі. Упродовж 1941-1969 рр. мовознавець уклав спеціальний словник слів із літерою “””, що налічував 1000 лексичних одиниць, включаючи історичні й етимологічні пояснення кожної 3 них. Особливо наголошував учений на необхідності вживання букви "г” у власних назвах іншомовного походження. Крім того, Я. Рудницький запропонував організувати роботу міжнародного комітету в складі українських і неукраїнських лінгвістів, щоб здійснювати неполітичний нагляд за роботою комісії та за впровадженням їі рекомендацій в Радянській Україні [14, с. 28].

Як відомо, літера “г” і кличний відмінок стали нормативними лише в редакції Українського правопису 1990 року. Однак і ця версія правописних норм, на думку вченого, потребувала уточнень. 1992 року Я. Рудницький став учасником “круглого столу" 3 теми "Український правопис: за і проти" (23.07.1992, Київ), виступив на конференції "Проблеми української науково-технічної термінологї̈” (10.10.1992, Львів) [15, с. 21-29]. 1993 року вчений бере участь у Міжнародній конференції “Фізика в Україні” (26.06.1993, Київ) і ставить свій підпис під “Термінологічною правописною конвенцією" з вимогами повернути новому 
правопису низку втрачених 1933 року позицій [4, с. 182]. У новій редакції Українського правопису 2019 року деякі з цих вимог реалізовано.

\section{Пропозиції “Термінологічної правописної конвенцї̈' учасників Міэнародної конференції “Фізика в Україні” 26 червня 1993 року і відповідні зміни в новій редакції Украӥнського правопису 2019 року}

\begin{tabular}{|c|c|}
\hline $\begin{array}{c}\text { Пропозиції “Термінологічної правописної } \\
\text { конвенції” (ухвалено на Міжнародній } \\
\text { конференції “Фізика в Україні” } 26 \text { червня } \\
1993 \text { року) }\end{array}$ & $\begin{array}{c}\text { Зміни в новій редакції Українського правопису } \\
2019 \text { року (ухвалено Постановою Кабінету } \\
\text { Міністрів № } 437 \text { від } 22 \text { травня } 2019 \text { р.) }\end{array}$ \\
\hline 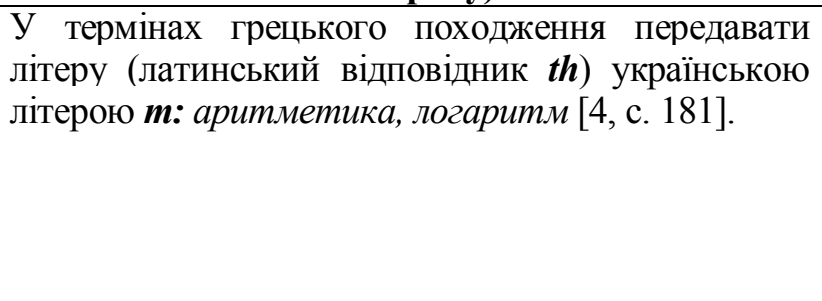 & 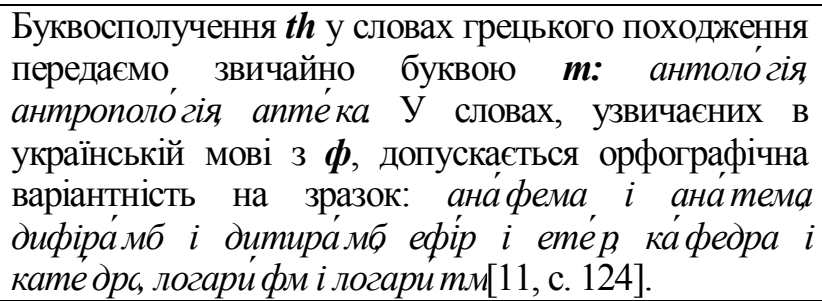 \\
\hline $\begin{array}{l}\text { У термінах грецького та латинського походження } \\
\text { сполучення aи передавати українським } \boldsymbol{a в} \\
\text { автентичний, авдіо }[4, \text { c. } 181] .\end{array}$ & 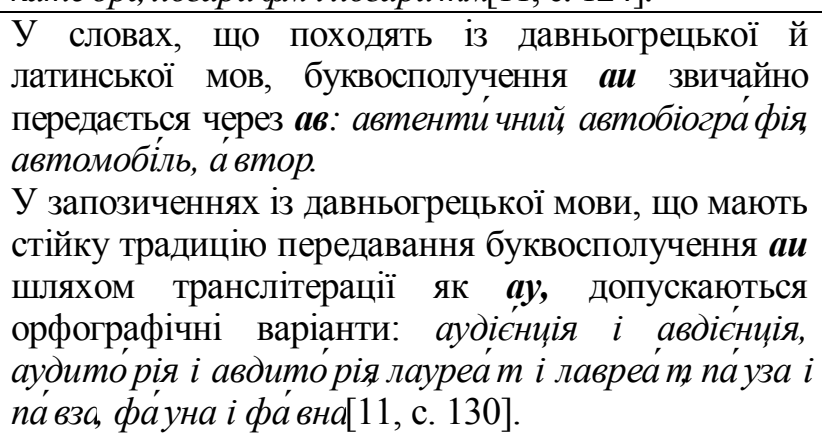 \\
\hline $\begin{array}{lcc}\text { У родовому відмінку іменники жіночого роду, що } \\
\text { в називному } & \text { відмінку } & \text { закінчуються на } \\
\text { приголосний, } & \text { писати } & \text { з закінченням } \\
\boldsymbol{u}: \text { властивости, валентности, соли }[4, \text { с. } 181] .\end{array}$ & 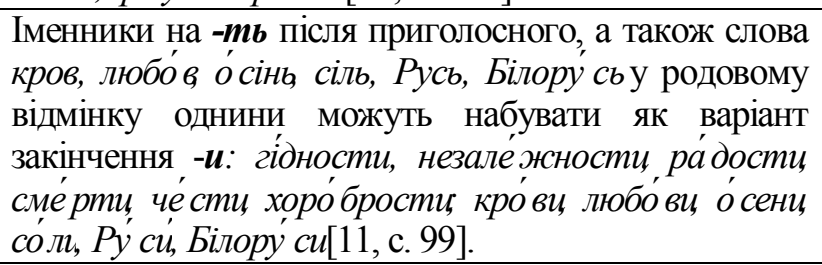 \\
\hline $\begin{array}{l}\text { Повернутися до притаманного українській мові } \\
\text { написання термінів : проєкт, проєкція [4, с. } 181] .\end{array}$ & 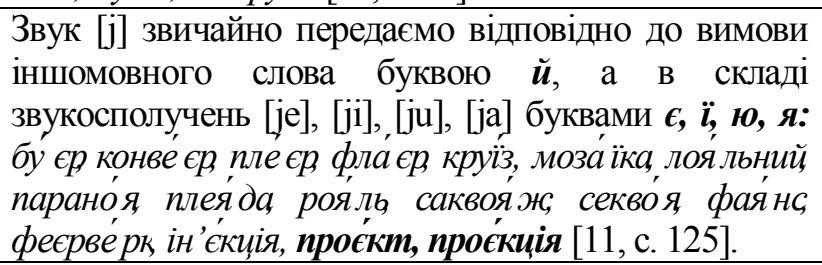 \\
\hline
\end{tabular}

Я. Рудницький розділяє думку І. Огієнка, що "рідній мові повинна відповідати рідна термінологія" - 3 прозорою внутрішньою формою, утворена на основі українських слів за правилами українського словотворення. Самодостатність абстрактної лексики української мови й термінології порівняно $з$ відповідними лексичними одиницями іншомовного походження Я. Рудницький утверджує в “Етимологічному словнику української мови” (1962-1982рр.), супроводжуючи реєстрові слова-запозичення синонімами власне українського та загальнослов'янського походження, наприклад: арzуме́ нm - Subst. dó вid, до́ каз [12, т. I, с. 30-31]; а́ втор - Subst. творе́ иь створи́ тель, винахідник; уклада́ч письме́ нник [12, т. I, с. 7]; анемо́на-, Subst. сон-трава́, сон-зілля, вітрянйця праліска [12, т. I, с. 25]; амбіція - Subst. почуття́ особи́ стої гідності честь; жадо́ба слави честилюбність, чванли́вість, пи́ха [12, т. I, с. 21]; аре́ шт - Subst. ув'язнення притри́мання придержа́ ння тюрма́ [12, т. I, с. 31]; бухга́лтер Subst. книгово́ д рахівни́ к [12, т. I, с. 277]; брандма́уер - Subst. противогневи́ қ протипоже́ жнй мур [12, т. I, с. 193]; -брах; брахі- - Subst. коротко-; е. g. брахікефа́л. короткоголо́ вещь брахіметропія: короткозо рість еts. [12, т. I, с. 197]; бу́ фер-Subst. відпру́ жниқ сте́ржень для 
осла́ блення по́ штовхів між ваго́ нами[12, т. I, с. 275]; exída - Subst. щзит, за́хист опі́ка, покро́ в [13, т. II, с. 243]; емболі́я - Subst. жилозасмічення [13, т. II, с. 269]; експеди́ція - Subst. випра́ ва, вир рядження [13, т. II, с. 253].

У мовознавчих працях Я. Рудницький використовує лінгвістичні терміни, які “прийняла i устійнила" Комісія мови Наукового Товариства імені Шевченка у Львові 1935-1936 рр. У публікаціях ученого знаходимо мовознавчі терміни українського походження, притаманні сучасній літературній мові (наприклад: гові́рка, звук, лапки́, час, ча́ стка тощо), з рисами західноукраїнського варіанта української мови (наприклад, назви відмінків: називни к родівни қ дава́льниқ знахідник, ору́ дниқ місие́ вик) або з відбитими на письмі особливостями діалектної західноукраїнської вимови (наприклад: йме́ нниқ йме́ ння дієйме́ нник). Часто трапляється парне використання термінів із мовознавчого арсеналу західноукраїнських лінгвістів і усталених у сучасній літературній мові, як-от: приголосні звуки - приголосівки, голосні звуки - голосівки [7, с. 8]; кома - проти́ нка, крапка з комою - сере́ дник[7, с. 53]. За потреби Я. Рудницький уживає терміни іншомовного походження (наприклад: флексія фонемма морфе́ма дерива́m), однак підкреслено демонструє можливість утворення і використання в науці української термінології, подаючи поруч із іншомовними українські варіанти, лінгвістичних термінів, наприклад: акузати́в- знахідник, ад'єкти́в - прикме́тник білабіа́л - дводу бий дента́льний - зубни́й, дейкти́ чний - вказівнй й, дифто́ нг - двозву́ қ дубле́ - двійня, фрикати вний-прити́ снений, артикуля ція-звукоутво́ рення, білабія льний-двогубнй й [7, с. 60-62].

У канадський період Я. Рудницький розвиває ще один важливий напрям мовознавчих досліджень, який радянські вчені “не могли чесно й неупереджено досліджувати”, соціолінгвістичний. Не маючи змоги аналізувати мовну ситуацію в Радянському Союзі, лінгвісти УРСР вивчали українсько-англійські мовні зв'язки в Канаді та США. Яскравим прикладом цього слугують книжки Ю. Жлуктенка “Мовні контакти” (1966), “Лингвистические аспекты двуязычия” (1974), “Українська мова на лінгвістичній карті Канади” (1990). У них автор намагається похитнути довіру до валідності досліджень канадських учених, зокрема Я. Рудницького, стосовно статусу української та інших емігрантських мов у Канаді.

Важливе значення для розуміння позиції Я. Рудницького як борця за мовні права українців УРСР у період холодної війни (1946-1990рр.) мають праці “За конституційне право української мови” (1967), “Language Rights and Linguicide’ (“Мовні права і лінгвіцид” (1967, 1968)), “Т проскрибована буква в СССР” (1970), “Linguicide” (“Лінгвіцид: мововбивство” (1976)), “Тhe Ems Ukase of 1876 and the Problem of Linguicide" ("Емський указ 1876 року і проблема лінгвіциду" (1976)), “Проти русифікації України. Лінгвіцид і Голодомор” (1984) тощо [3, с. 525].

1967 року Я. Рудницький уперше письмово використовує термін лінгвіuид в індивідуальному "Меншинному звіті", опублікованому в першому томі офіційних рапортів “B\&B Commission” (1967) [13, т. II, c. 775]. Зауважмо, що в сучасній українській соціолінгвістиці використовують термін лінгвоџид [6], а західноєвропейські й американські мовознавці вживають термін linguicide (лінтвіuид) [5, с. 318], та суть цих термінів одна і та ж: мововбивство, тобто свідоме, цілеспрямоване нищення певної мови як головної ознаки етносу (народності, нації).

У роботі “Емський указ 1876 року і проблема лінгвіциду”(1976) Я. Рудницький утверджує думку про дотримання мовних прав усіх членів суспільства та про необхідність державного захисту мови, визначає перелік факторів, які вважає “лінгвіцидними", а саме: убивство носіїв мови (геноцид); репресивні заходи, що заважають природному розвиткові мови; насильницьке трансформування двомовного суспільства в одномовне; нав'язування чужої мови шляхом обов'язкового вивчення iii в школі, через засоби масової інформації; відсутність державної підтримки культурного розвитку національних меншин [14, с. 99]. Негативний вплив усіх цих чинників на розвиток української мови в УРСР підтверджено історичними документами, вміщеними в збірнику за редакцією Л. Масенко "Українська мова у ХХ столітті: історія лінгвоциду. Документи і матеріали” [6]. Висновок Я. Рудницького про необхідність захисту української мови на державному рівні підтримують сучасні дослідники: П. Гриценко, О. Кочерга, Л. Масенко, П. Селігей та ін. [2; 4; 6; 9].

Зауважмо, що в переліку “лінгвіцидних” заходів на першому місці - Голодомор. 1 січня 
1983 року Я. Рудницький, на той час голова уряду УНР у вигнанні (1980-1989 рр.), відвідав штаб-квартиру Міжнародного співтовариства у Нью-Йорку й передав на ім'я Генерального секретаря ООН меморандум про Голод-Голокост в Україні в 1932-1933 pp., а 24 червня 1984 року у Вінніпезі встановлено перший у світі пам'ятник жертвам Голодомору. Генеральна асамблея ООН визнала Голодомор 30-тих років національною трагедією українського народу в 2003 році, а Верховна Рада України - у 2006 році.

Висновки. Наукова та громадсько-політична діяльність Я. Рудницького канадського періоду (1949-1995рр.) відбиває основні аспекти ідеологічного протистояння радянської тоталітарної системи і демократичного Заходу. Тематика і глибина лінгвістичних праць, присвячених проблемам збереження правописних норм української літературної мови та наукової термінології, захисту мовних прав українців на рівні держави, засвідчила утвердження самодостатності української мовознавчої науки і стала потужним чинником іiі розвитку.

\section{References}

1. Hluschenko, Volodymyr. 1998. Pryntsypy porivnialno-istorychnoho doslidzhennia v ukrainskomu i rosiyskomu movoznavstvi (70-i rr. XIX st. - 20-i rr. XX st.). Donetsk.

2. Hrytsenko, Pavlo. 2001. "Profesor Oleksa Horbach i yoho vydannia pamiatok ukrainskoi movy". Pamiatky Ukrainy: istoriia ta kultura 1-2: 118-121.

3. Zorivchak, Roksolina. 2000. "Rudnytskyi Yaroslav-Bohdan". Ukrainska mova. Entsyklopediya. Kyiv.

4. Kocherha, Olha 1994. "Deiaki mirkuvannia pro shliakhy i manivtsi rozvidky ukrainskoi terminolohii." Suchasnist 7-8: 173-182.

5. "Linhvotsyd". 2000. Ukrainska mova. Entsyklopediia. Kyiv.

6. Masenko, Larysa. 2005. Ukrainska mova u XX stolitti: istoriia linhvotsydu. Dokumenty i materialy. Kyiv.

7. Rudnytskyi, Yaroslav. 1949. Ukrainskyi pravopys. Vinnipeh: Komitet ukraintsiv v Kanadi.

8. Rudnytskyi, Yaroslav. 1948. "Ukrainska slavistyka ta yii zavdannia". Zavdannia slovianskoi filolohii i ukrainska slavistyka. Auhsburh.

9. Selihei, Pylyp. 2017. "Sotsiolinhvistyka: pratsia, natkhnennia, poklykannia (do iuvileiu Larysy Masenko)". Mova: klasychne - moderne - postmoderne. Kyiv: Dukh i Litera 3: 6-19.

10. Simovych, Vasyl and Rudnytskyi, Yaroslav. 1994-1995. Istoriia ukrainskoho pravopysu. Entsyklopediia ukrainoznavstva: zahalna chastyna. http://litopys.org.ua/entsytsl/eui036.htm

11. Ukrainskyi pravopys. 2019. https://mon.gov.ua/storage/app/media/zagalna\% 20serednia/\%202019.pdf.

12. Rudnyckyi, Yaroslav. 1972. An Etymological Dictionary of the Ukrainian Language. Vol. I. Winnipeg: Ukrainian Free Academy of Sciences.

13. Rudnyckyi, Yaroslav. 1982. An Etymological Dictionary of the Ukrainian Language. Vol. II. Ottawa: Ukrainian Mohylo-Mazepian Academy of Sciences.

14. Rudnyckyi, Yaroslav. 1976. Linguicide. Winnipeg; Munchen.

15. Rudnyckiana 10: 1-49.

16. Woycenko, Olha. 1992. The Annals of Ukrainian life in Canada: Striving for a New Canada. Official Bilingualism and Multiculturalism 1970-1979. Edmonton.

Гапон Леся. Лингвистические исследования Ярослава - Богдана Рудницкого в Канаде как феномен периода идеологического противостояния. В статье проанализированы работы Я. Рудницкого канадского периода (1949-1995 гг.) - времени идеологического противостояния советской и западной систем - с целью определения влияния научной позиции ученого диаспоры на развитие отдельных направлений современной украинской лингвистики.

Кратко охарактеризирована научная деятельность Я. Рудницкого в Канаде, раскрыты взгляды языковеда на роль славистов диаспоры в период тоталитарного давления на украинистику в СССР.

Показана весомая роль ученого в борьбе за сохранение норм харьковского правописания как в среде эмигрантов, так и в материковой Украине. Приведены факты личного участия Я. Рудницкого в научных дискуссиях и гражданско-политических акциях, касающихся возврата в украинскую азбуку буквы “ґ”, восстановления отдельных падежных форм и транслитерации заимствованных слов.

Освещена позиция Я. Рудницкого о значении сохранения украинской научной терминологической лексики, образованной на основе исконных слов сравнительно с украинскими деривационными моделями.

Значительное внимание уделено социолингвистическому направлению исследований автора канадского периода, касающихся описания условий развития украинского языка в УССР. Выделены ключевые аспекты концепции “лингвицида”, автором которой является Я. Рудницкий, определены “лингвицидные” факторы, отмечена важность использования ученым возможностей демократического Запада в процессе отстаивания права украинского языка на самостоятельное развитие и защиту со стороны государства.

В работе использованы биографический метод, метод анализа лингвистической литературы, сопоставительный и актуализационный методы.

Взгляды автора показаны в сравнении с выводами современных украинских исследователей. Описание 
лингвистических процессов, касающихся особенностей становления и развития украинской социолингвистики, научной терминологии и правописания отражено с учетом влияния на них исторических и социокультурных факторов периода идеологического противостояния с проекцией на современность.

Ключевые слова: лингвоисториография, диаспора, правописание, научная терминология, социолингвистика, лингвоцид.

Hapon Lesia. Yaroslav Bohdan Rudnytsky's Linguistic Research in Canada as a Phenomenon of an Era of Ideological Confrontation. Yaroslav Rudnytsky's works of the Canadian period (1949-1995) of ideological confrontation between the Soviet and Western systems are analyzed.

The purpose of the article is to consider Yaroslav Rudnytsky's academic achievements and to characterize the influence of his ideas on some directions of modern Ukrainian linguistics.

A linguist's contribution to the development of Ukrainian science in Canada is valued. The views of the linguist on the role of Slavic diaspora in the period of totalitarian pressure on Ukrainian studies in the USSR are highlighted.

The efforts of the scholar to preserve literary language standards, orthographic in particular, based on Kharkiv edition of "Ukrainian Spelling" in the environment of emigrants as well as in mainland Ukraine are shown. The facts of Ya roslav Rudnitsky's personal participation in scientific discussions and social and political actions on the need to return the letter " " $"$ " to the Ukrainian alphabet, restore some distinctive forms and transliteration of foreign language borrowings are presented.

Yaroslav Rudnytsky's contribution to the development of Ukrainian scientific terminology formed on the basis of specific words according to Ukrainian derivative models is highlighted.

Special attention is paid to sociolinguistic part of the linguistic studies of the author. The problems and perspectives of Ukrainian language functioning in mainland Ukraine and in Diaspora in the linguist's interpretation are elucidated. The concept of "linguicide" is analyzed. The "linguicide" factors are highlighted, the importance of using the opportunities of the democratic West in the process of defending the right of the Ukrainian language to independent development and protection by the state is noted.

The author's views are compared with contemporary scholar's investigations. While describing language processes, we reproduce the historical background and socio-cultural approaches, trace positive trends in modern Ukrainian sociolinguistics, scientific terminology and orthography.

Keywords: linguistic historiography, Diaspora, orthography, linguistic terms, sociolinguistics, linguicide.

DOI: https://doi.org/10.32782/2410-0927-2020-12-10

УДК $81 ’ 255=111=161.2: 659.1$

Юлія Головацька

\section{RENDRING OF THE PHRASEOLOGICAL UNITS AS MEANS OF CHARACTER DESCRIPTION IN UKRAINIAN AND POLISH TRANSLATIONS OF “ALICE THROUGH THE LOOKING GLASS” BY LEWIS CARROLL}

The article deals with the peculiarities of the reproduction of phraseological units as means of character formation in the translations of the novel "Alice Through the Looking Glass" into Ukrainian and Polish. The classification of phraseological units in terms of translation studies is presented. The methods of translation of phraseological units are defined (translation by phraseological equivalent, phraseological analogue, descriptive translation, contextual substitutions and calculations, use of appropriate phraseologism in the target language). The classification of phraseological units by their semantics (common phrases (units where the freedom of choice is limited); phraseological groups (express one but complex concept); phraseological unities (one indivisible unit) is analyzed. It is defined that phraseological fusion is a semantically indivisible phraseological unit and its meaning is never influenced by the meanings of its components; phraseological unity is a semantically indivisible phraseological unit the whole meaning of which is motivated by the meanings of its components; phraseological combination is a semantically divisible phraseological unit in which every word has absolutely independent meaning while one of the components has a bound meaning. Functional classification of phraseologisms in the novel "Alice Through the Looking Glass" (phraseologisms related to the characteristics of characters (both from the positive and the negative side); phraseological units rendering the character's inner state; phraseological units that help to reveal the character's physical state; phraseologisms characterizing the rich spiritual world of a character, his or her wisdom and wittiness) is given. Phraseologisms that relate to the characteristics of the characters and perform the evaluative function are thematically divided into the following groups: phrases that help to reveal the positive qualities of the characters; phrases that contribute to the disclosure of negative qualities; phrases that complement the portrait characteristics. Ways of translating of the phraseological units into Ukrainian and Polish are investigated. The analysis of 150 phraseological units led to the conclusion that there are several ways to translate a phraseological unit depending on which group it belongs to. There are such ways of translating phraseological units - translation of the phraseological equivalent, phraseological analogue, descriptive translation, contextual replacements, and loan translation.

Key words: phraseologism, translation, character, character formation.

(С) Головацька Ю., 2020 